\title{
UJI AKTIVITAS ANTIOKSIDAN EKSTRAK BUAH SENGGANI (Melastoma malabathricum L.) DAN EKSTRAK BUAH BIT (Beta vulgaris L.)
}

\author{
Septiani \\ Program Studi Teknologi Laboratorium Medis, FST Universitas Binawan \\ Jl. Raya KalibataRaya ,Cawang, Kramat Jati, Jakarta Timur, Jakarta 13630 \\ Email: septiani@binawan.ac.id
}

\begin{abstract}
Abstrak
Penelitian ini dilakukan dengan tujuan untuk mengetahui jenis metabolit sekunder dan aktivitas antioksidan dari buah senggani (Melastoma malabathricum L.) dan ekstrak buah bit (Beta vulgaris L.). Ekstrak buah senggani dan buah bit diperoleh dengan cara maserasi. Pengujian antioksidan dilakukan dengan metode peredaman radikal bebas oleh 2,2-diphenyl-1-picrylhydrazyl (DPPH). Hasil penelitian berdasarkan pengujian skrining fitokimia menunjukkan bahwa ekstrak buah senggani dan buah bit memiliki kandungan senyawa metabolit sekunder golongan alkaloid, flavonoid, dan tanin. Hasil penelitian berdasarkan pengujian antioksidan diperoleh berdasarkan nilai absorbansi dan nilai \% inhibisi. Nilai \% inhibisi tertinggi buah senggani dan buah bit diperoleh pada konsentrasi yang sama, yaitu $10 \mathrm{ppm}$ sebesar $70,14 \%$ dan 55,87\%. Nilai $\mathrm{IC}_{50}$ dari ekstrak buah senggani dan buah bit menunjukkan aktivitas antioksidan yang sangat kuat yaitu sebesar 4,63 ppm dan 7,77 ppm. Berdasarkan penelitian ini, dapat disimpulkan bahwa ekstrak buah senggani (Melastoma malabathricum L.) dan buah bit (Beta vulgaris L.) berpotensi sebagai antioksidan dan mampu menghambat radikal bebas.
\end{abstract}

Kata Kunci: buah bit, buah senggani, aktivitas antioksidan

\begin{abstract}
This research was conducted with the aim of knowing the type of secondary metabolites and antioxidant activity of senggani (Melastoma malabathricum L.) and beet (Beta vulgaris L.) fruit extracts. Senggani and beetroot extracts were obtained by maceration. Antioxidant testing was carried out by the method of reducing free radicals by 2,2-diphenyl-1-picrylhydrazyl (DPPH). The results of the study based on phytochemical screening tests showed that the extracts of senggani and beets contained secondary metabolites of alkaloids, flavonoids and tannins. The results of the study based on antioxidant testing were obtained based on the absorbance value and the\% inhibition value. The highest $\%$ inhibition value of senggani fruit and beet fruit was obtained at the same concentration, namely $10 \mathrm{ppm}$ of $70.14 \%$ and $55.87 \%$. The IC50 values of senggani and beet fruit extracts showed very strong antioxidant activity, namely $4.63 \mathrm{ppm}$ and $7.77 \mathrm{ppm}$. Based on this research, it can be concluded that the extracts of senggani (Melastoma malabathricum L.) and beets (Beta vulgaris L.) have the potential as antioxidants and can inhibit free radicals.
\end{abstract}

Keywords: Beetroot, senggani fruit, antioxidant activity 


\section{PENDAHULUAN}

Di Indonesia banyak masyarakat yang menderita penyakit-penyakit degeneratif, seperti kanker, diabetes, jantung, artritis, dan lainnya. Hal yang menjadi salah satu penyebab timbulnya penyakit-penyakit tersebut adalah karena meningkatnya konsentrasi radikal bebas yang tidak mampu lagi dinetralisir oleh antioksidan di dalam tubuh. Radikal bebas merupakan sekelompok atom atau molekul yang pada kulit terluarnya memiliki satu atau lebih elektron tidak berpasangan, yaitu elektron yang sendirian di dalam orbital. Elektron tidak berpasangan ini menyebabkan radikal bebas sangat reaktif dan akan menangkap elektron dari makromolekulmakromolekul di sekitarnya seperti protein, lipid, karbohidrat, dan DNA untuk menetralkan diri, sehingga menyebabkan timbulnya kerusakan pada sel-sel tersebut, seperti penyakit degeneratif (Santoso, 2016).

Antioksidan merupakan zat yang dapat menangkal atau mencegah reaksi oksidasi berantai dari radikal bebas pada konsentrasi yang rendah (Santoso, 2016). Adanya antioksidan dapat berperan sebagai penetral radikal bebas, sehingga menghambat proses kerusakan yang ditimbulkannya. Salah satu sumber antioksidan alami yaitu berasal dari tanaman, seperti pada daun, buah, dan bunganya. Senyawa pada tanaman banyak terkandung berbagai molekul penghambat radikal bebas, seperti senyawa fenolik (asam fenolik, flavonoid, lignan, tanin, kuinon, kumarin, dan stilbenes), senyawa nitrogen (alkaloid, betalanin, dan amina), dan terpenoid (karotenoid) (Ivanisova et al., 2013). Beberapa penelitian telah menunjukkan bahwa adanya senyawa fenol sangat berperan dalam aktivitas antioksidan. Senyawa fenol merupakan salah satu senyawa metabolit sekunder turunan benzena yang memilki gugus $\mathrm{OH}$ pada strukturnya.

Salah satu senyawa metabolit sekunder yang memiliki kemampuan sebagai antioksidan adalah dari golongan senyawa flavonoid, yaitu antosianin. Antosianin yang terkandung dalam tanaman merupakan pigmen alami yang biasanya berwarna ungu, biru, merah, dan agak hitam, serta dapat larut dalam air. Antosianin dapat ditemukan di semua bagian jaringan tanaman termasuk batang, akar, daun, bunga, dan buah. Pigmen warna dari antosianin lebih melimpah, mudah diekstraksi, lebih aman, dan ramah lingkungan (Hasby et al., 2019).

Secara umum, senyawa flavonoid memiliki fungsi sebagai antioksidan primer, scavenger dan chelator terhadap superoksida anion, sehingga antosianin menjadi lebih aktif dalam bentuk aglikon dibandingkan dengan bentuk glikosidanya. Berdasarkan uraian di atas, maka penulis terdorong untuk melakukan penelitian tentang "Uji Aktivitas Antioksidan Ekstrak buah senggani (Melastoma malabathricum L.) dan ekstrak buah bit (Beta vulgaris L.)".

\section{METODOLOGI PENELITIAN}

\section{Pembuatan Ekstrak Buah Senggani dan Buah Bit}

Dipotong dan dihaluskan buah senggani dan buah bit sebanyak $100 \mathrm{gr}$ menggunakan blender. Selanjutnya, diekstraksi buah senggani dan buah bit dengan merendamnya menggunakan pelarut etanol $96 \%$ dan ditutup menggunakan aluminium foil. Sampel yang telah diekstraksi, kemudian dimasukkan ke dalam botol vial. 


\section{Pengujian Flavonoid}

Dimasukkan $2 \mathrm{~mL}$ ekstrak buah senggani dan buah bit ke dalam masingmasing tabung reaksi, dan ditambahkan 0,1 gram logam $\mathrm{Mg}$ dan 5 tetes $\mathrm{HCl}$ pekat. Terbentuknya warna merah atau jingga, maka sampel positif mengandung adanya senyawa flavonoid (Mustapa et al., 2017).

\section{Pengujian Alkaloid}

Dimasukkan $2 \mathrm{~mL}$ ekstrak buah senggani dan buah bit ke dalam masingmasing tabung reaksi, dan ditambahkan 5 tetes $\mathrm{HCl}$ pekat dan 5 tetes reagen Dragendroff, Maeyer, dan Wagner. Terbentuknya endapan menunjukkan bahwa sampel positif mengandung senyawa alkaloid, yaitu endapan merah jingga untuk pereaksi Dragendroff, endapan putih untuk pereaksi Maeyer, dan endapan cokelat untuk pereaksi Wagner (Afnidar, 2014).

\section{Pengujian Tanin}

Dimasukkan $2 \mathrm{~mL}$ ekstrak buah senggani dan buah bit ke dalam masingmasing tabung reaksi, dan ditambahkan 5 tetes $\mathrm{FeCl}_{3}$ 1\%. Terbentuknya warna hijau kehitaman, maka sampel positif mengandung senyawa tanin.

\section{Pengujian Antioksidan}

Terlebih dahulu disiapkan larutan induk sampel dengan konsentrasi 100 ppm, yaitu $10 \mathrm{mg}$ masing-masing ekstrak dilarutkan dalam $100 \mathrm{~mL}$ metanol p.a. Selanjutnya, dilakukan pengenceran dengan membuat variasi konsentrasi sebesar $0 \mathrm{ppm}$, 2 ppm, 4 ppm, 6 ppm, 8 ppm, dan 10 ppm pada tiap masing-masing ekstrak sampel.

Langkah selanjutnya, disiapkan larutan stock DPPH sebanyak 50 ppm, yaitu dengan melarutkan $5 \mathrm{mg}$ serbuk DPPH ke dalam $100 \mathrm{~mL}$ metanol p.a. Kemudian disiapkan larutan kontrol, yaitu $2 \mathrm{~mL}$ metanol p.a dan $1 \mathrm{~mL}$ larutan DPPH 50 ppm.

Untuk sampel uji, disiapkan masingmasing $2 \mathrm{~mL}$ larutan induk sampel dan $2 \mathrm{~mL}$ larutan DPPH (larutan kontrol). Selanjutnya, diinkubasi selama 30 menit pada suhu $37^{\circ} \mathrm{C}$ sampai terjadi perubahan warna akibat aktivitas DPPH. Diulangi perlakuan semua sampel sebanyak 3 kali (triplo). Kemudian, dilakukan pengujian antioksidannya dengan cara mengukur nilai absorbansinya menggunakan spektrofotometer UV-VIS pada panjang gelombang $517 \mathrm{~nm}$.

\section{Penentuan Nilai Concentration (IC50)}

Pengujian antioksidan dengan metode DPPH dianalisis dari proses berubahnya warna pada masing-masing ekstrak sampel setelah diinkubasi dengan DPPH. Apabila semua elektron radikal bebas (DPPH) telah berpasangan dengan elektron pada tiap ekstrak sampel, maka perubahan warna yang terjadi adalah dari berwarna ungu tua hingga menjadi kuning terang. Kemudian sampel diukur nilai absorbansinya menggunakan spektrofotometer UV-VIS pada panjang gelombang $517 \mathrm{~nm}$ sebanyak 3 kali pengulangan (triplo). Metode spektrofotometri ini biasanya digunakan sebagai tahap awal dalam mempelajari proses transisi elektronik atau eksitasi elektronik molekul yang menghasilkan reaksi fotokimia yang diinduksi oleh penyerapan sinar ultraviolet (UV) atau cahaya tampak (Vis) (Hasby et al., 2020).

\section{HASIL DAN PEMBAHASAN}

Pada pembuatan ekstrak etanol buah senggani dan buah bit diekstrak dengan cara maserasi. Buah senggani dan buah bit yang tersedia kemudian dipotong-potong dan diblender sehingga diperoleh bubur buah senggani dan buah bit. Dari bubur tersebut 
ditimbang sebanyak 100 gram untuk direndam (maserasi) menggunakan pelarut etanol sebanyak $100 \mathrm{~mL}$ dan ditutup dengan aluminium foil. Selanjutnya, maserat disaring menggunakan kertas saring. Apabila volume maserat yang diperoleh kurang dari $100 \mathrm{~mL}$, maka ditambahkan dengan etanol hangat melalui residu saringan hingga volumenya mencapai 100 $\mathrm{mL}$, sehingga didapatkan ekstrak buah senggani berwarna merah dan ekstrak buah bit berwarna merah gelap.

Tahap awal kegiatan penelitian adalah menentukan kandungan metabolit sekunder pada buah senggani dan buah bit. Penentuan dilakukan dengan teknik skrining fitokimia. Hasil yang diperoleh yaitu sampel ekstrak mengandung beberapa kelompok senyawa aktif seperti flavonoid, alkaloid dan tanin. Untuk lebih jelasnya, hasil pengamatan kualitatif senyawa metabolit sekunder pada ekstrak buah senggani dan buah bit dapat lihat pada Tabel 1 .

Tabel 1. Hasil Skrining Fitokimia Ekstrak Buah Senggani (Melastoma malabathricum L.) dan Buah Bit (Beta vulgaris L.)

\begin{tabular}{|c|c|c|c|}
\hline No & Perlakuan & $\begin{array}{c}\text { Hasil } \\
\text { Pengamatan }\end{array}$ & Keterangan \\
\hline \multicolumn{4}{|c|}{ Ekstrak Buah Senggani } \\
\hline 1 & $\begin{array}{l}\text { Uji Flavonoid } \\
2 \mathrm{~mL} \text { ekstrak } \\
\text { buah senggani } \\
+0,1 \text { g logam } \\
\mathrm{Mg}+5 \text { tetes } \\
\mathrm{HCl} \text { pekat }\end{array}$ & $\begin{array}{l}\text { Menghasilkan } \\
\text { larutan } \\
\text { berwarna } \\
\text { kuning jingga }\end{array}$ & $(+++)$ \\
\hline 2 & $\begin{array}{l}\text { Uji Alkaloid } \\
2 \text { mL ekstrak } \\
\text { buah senggani } \\
+5 \text { tetes } \mathrm{HCl} \\
\text { pekat }+5 \text { tetes } \\
\text { reagen } \\
\text { Dragendroff }\end{array}$ & $\begin{array}{l}\text { Menghasilkan } \\
\text { endapan } \\
\text { berwarna } \\
\text { jingga }\end{array}$ & $(++)$ \\
\hline 3 & $\begin{array}{l}\text { Uji Tanin } \\
2 \mathrm{~mL} \text { ekstrak } \\
\text { buah senggani } \\
+1 \mathrm{~mL} \mathrm{FeCl}_{3}\end{array}$ & $\begin{array}{l}\text { Larutan } \\
\text { berwarna hijau } \\
\text { kehitaman }\end{array}$ & $(++)$ \\
\hline
\end{tabular}

\begin{tabular}{|c|c|c|c|}
\hline \multicolumn{4}{|c|}{ Ekstrak Buah Bit } \\
\hline 1 & $\begin{array}{l}\text { Uji Flavonoid } \\
2 \text { mL ekstrak } \\
\text { buah bit }+0,1 \\
\text { g logam } \mathrm{Mg}+ \\
5 \text { tetes } \mathrm{HCl} \\
\text { pekat }\end{array}$ & $\begin{array}{l}\text { Menghasilkan } \\
\text { larutan } \\
\text { berwarna } \\
\text { kuning jingga }\end{array}$ & $(++)$ \\
\hline 2 & $\begin{array}{l}\text { Uji Alkaloid } \\
2 \mathrm{~mL} \text { ekstrak } \\
\text { buah bit }+5 \\
\text { tetes } \mathrm{HCl} \text { pekat } \\
+5 \text { tetes } \\
\text { reagen } \\
\text { Dragendroff }\end{array}$ & $\begin{array}{l}\text { Menghasilkan } \\
\text { endapan } \\
\text { berwarna } \\
\text { jingga }\end{array}$ & $(++)$ \\
\hline 3 & $\begin{array}{l}\text { Uji Tanin } \\
2 \mathrm{~mL} \text { ekstrak } \\
\text { buah bit }+1 \\
\mathrm{~mL} \mathrm{FeCl}_{3}\end{array}$ & $\begin{array}{l}\text { Larutan } \\
\text { berwarna hijau } \\
\text { kehitaman }\end{array}$ & $(+++)$ \\
\hline
\end{tabular}

Keterangan: Hasil negatif $=(-)$, Hasil positif lemah $=(+)$, Hasil positif kuat $=(++)$, Hasil positif sangat kuat $=(+++)$

Penelitian ini dilakukan untuk menguji aktivitas antioksidan menggunakan metode DPPH. Metode ini dipilih karena lebih sederhana dibandingkan metode pengujian antioksidan lainnya. Hasil dari pengukuran aktivitas antioksidan ekstrak sampel menggunakan larutan pembanding, yaitu Vitamin C (Asam askorbat). Alasan digunakannya Vitamin $\mathrm{C}$ sebagai pembanding, dikarenakan merupakan senyawa yang telah diketahui mempunyai aktivitas antioksidan yang sangat kuat. Kemampuan inilah yang membuat Vitamin C mampu mengikat radikal oksigen sehingga tidak terjadi reaksi oksidasi (Hanani, 2005).

Pengujian aktivitas antioksidan dilakukan dengan cara mereaksikan larutan uji (sampel) dengan DPPH. Jika larutan uji (sampel) yang mengandung suatu senyawa yang berfungsi sebagai antioksidan saat direaksikan dengan DPPH, maka ketika bereaksi, larutan sampel akan mereduksi DPPH menjadi DPPH-H (Difenilpikril hidrazin) yang stabil, sehingga warna DPPH 
yang semulanya ungu akan berubah menjadi warna kuning. Selanjutnya, setelah terjadi reduksi sampel terhadap DPPH, maka pengujian aktivitas antioksidan dilanjutkan dengan pengukuran absorbansi menggunakan spektrofotometer UV-Vis. Hasil pengukuran absorbansi buah senggani dapat dilihat pada Tabel 2.

Tabel 2. Data Hasil Uji Antioksidan Ekstrak Buah Senggani (Melastoma malabathricum L.)

\begin{tabular}{|c|c|c|c|}
\hline $\begin{array}{l}\text { Konsentrasi } \\
\text { (ppm) }\end{array}$ & $\begin{array}{c}\text { Absorbansi Rata-rata } \\
\text { (ppm) }\end{array}$ & $\begin{array}{c}\% \\
\text { Inhibisi }\end{array}$ & $\begin{array}{c}\mathrm{IC}_{50} \\
(\mathrm{ppm})\end{array}$ \\
\hline 0 & 0,345 & 0 & \multirow{6}{*}{4,63} \\
\hline 2 & 0,194 & 43,77 & \\
\hline 4 & 0,174 & 49,56 & \\
\hline 6 & 0,150 & 56,52 & \\
\hline 8 & 0,115 & 66,67 & \\
\hline 10 & 0,103 & 70,14 & \\
\hline
\end{tabular}

Hasil yang didapatkan pada tabel diatas menunjukkan semakin besar konsentrasi, nilai absorbansi semakin menurun dan persen inhibisi semakin meningkat. Persen inhibisi didapatkan dari perbedaan antara serapan absorban blanko dan absorban sampel. Kemudian $\mathrm{IC}_{50}$ dapat diukur dengan membuat persamaan regresi linear antara konsentrasi dan persen inhibisi sampel. Kurva regresi linear ekstrak buah senggani dapat dilihat pada Gambar 1.

\section{Buah Senggani (Melastoma malabathricum L.)}

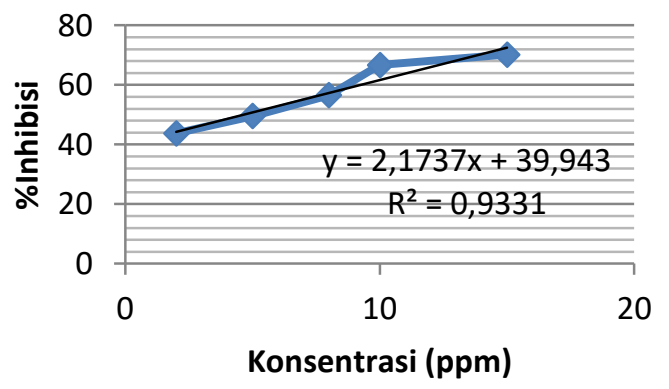

Gambar 1. Kurva Regresi Linear Ekstrak Buah Senggani (Melastoma malabathricum L.)
Nilai $\mathrm{IC}_{50}$ adalah bilangan yang menyatakan besarnya konsentrasi ekstrak sampel yang mampu memperlambat aktivitas radikal bebas sebesar 50\%. Jika semakin kecil nilai $\mathrm{IC}_{50}$ yang diperoleh, maka semakin tinggi aktivitas antioksidan ekstrak sampel tersebut (Rahmayani et al., 2013). Adanya hasil nilai $\mathrm{IC}_{50}$ bisa diperoleh dengan cara mensubstitusikan nilai y menjadi 50 pada persamaan $\mathrm{y}=2,173 \mathrm{x}+39,94$., maka didapat nilai $\mathrm{IC}_{50}$ buah senggani adalah sebesar 4,63 ppm. Hal ini menunjukkan bahwa buah senggani memilki aktivitas antioksidan yang sangat kuat ( $<50 \mathrm{ppm})$. Menurut Mardawati (2008) suatu senyawa dikatakan sebagai antioksidan sangat kuat jika nilai $\mathrm{IC}_{50}<50 \mathrm{ppm}$, kuat (50-100) ppm, sedang (100-150) ppm, dan lemah (151-200) ppm.

Penyebab buah senggani memliki aktivitas antioksidan yang tinggi, dikarenakan kandungan senyawa metabolit sekunder yang dimilikinya, yaitu senyawa alkaloid, flavonoid, dan tanin. Menurut Handayani et al., (2014), bahwa alkaloid memiliki kemampuan untuk menghentikan reaksi berantai pada radikal bebas secara efisien. Selanjutnya, Flavonoid yang merupakan senyawa polifenol memiliki kemampuan untuk menyumbangkan atom hidrogennya kepada radikal bebas. Buah senggani juga mengandung pigmen antosianin yang menyebabkan warna merah keunguan pada buah senggani. Antosianin merupakan senyawa flavonoid yang memiliki fungsi sebagai antioksidan.

Selanjutnya akan dibahas mengenai pengujian aktivitas antioksidan ekstrak buah bit. Hasil pengukuran absorbansi ekstrak buah bit dapat dilihat pada Tabel 3 . 
Tabel 3. Data Hasil Uji Antioksidan Buah Bit (Beta vulgaris L.)

\begin{tabular}{|c|c|c|c|}
\hline $\begin{array}{c}\text { Konsentrasi } \\
(\mathbf{p p m})\end{array}$ & $\begin{array}{c}\text { Absorbansi Rata-rata } \\
\text { (ppm) }\end{array}$ & $\begin{array}{c}\% \\
\text { Inhibisi }\end{array}$ & $\begin{array}{c}\mathrm{IC}_{50} \\
(\mathbf{p p m})\end{array}$ \\
\hline 0 & 0,689 & 0 & \multirow{6}{*}{7,77} \\
\hline 2 & 0,475 & 31,05 & \\
\hline 4 & 0,388 & 43,68 & \\
\hline 6 & 0,369 & 46,44 & \\
\hline 8 & 0,353 & 48,76 & \\
\hline 10 & 0,304 & 55,87 & \\
\hline
\end{tabular}

Hasil yang didapatkan pada tabel diatas menunjukkan semakin besar konsentrasi, nilai absorbansi semakin menurun dan persen inhibisi semakin meningkat. Persen inhibisi didapatkan dari perbedaan antara serapan absorban blanko dan absorban sampel. Kemudian $\mathrm{IC}_{50}$ dapat diukur dengan membuat persamaan regresi linear antara konsentrasi dan persen inhibisi sampel. Kurva regresi linear ekstrak buah bit dapat dilihat pada Gambar 2.

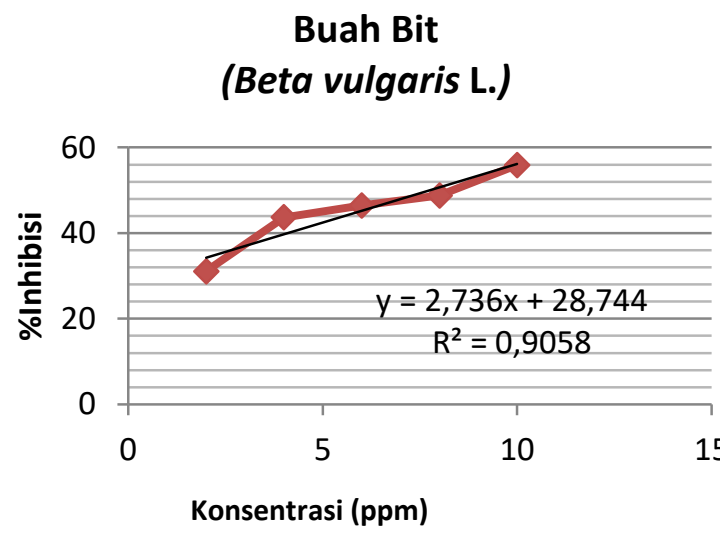

Gambar 2. Kurva Regresi Linear Ekstrak Buah Bit (Beta vulgaris L.)

Nilai $\mathrm{IC}_{50}$ adalah bilangan yang menyatakan besarnya konsentrasi ekstrak sampel yang mampu memperlambat aktivitas radikal bebas sebesar 50\%. Jika semakin kecil nilai $\mathrm{IC}_{50}$ yang diperoleh, maka semakin tinggi aktivitas antioksidan ekstrak sampel tersebut (Kartikasari dkk, 2018). Adanya hasil nilai $\mathrm{IC}_{50}$ bisa diperoleh dengan cara mensubstitusikan nilai y menjadi 50 pada persamaan $\mathrm{y}=2,736 \mathrm{x}+28,74$., maka didapat nilai $\mathrm{IC}_{50}$ buah bit adalah sebesar 7,77 ppm. Hal ini menunjukkan bahwa buah senggani memilki aktivitas antioksidan yang sangat kuat (<50 ppm). Namun, berdasarkan nilai $\mathrm{IC}_{50}$ yang diperoleh, aktivitas antioksidan buah bit lebih kecil dibandingkan dengan buah senggani.Sama halnya dengan buah senggani, buah bit memliki aktivitas antioksidan yang tinggi karena mengandung senyawa alkaloid, flavonoid, dan tanin.

Vitamin $\mathrm{C}$ digunakan sebagai kontrol positif (pembanding). Karena memilki aktivitas antioksidan yang sangat kuat dengan $\mathrm{IC}_{50}$ sebesar 0,93. Data pengujian antioksidan pada Vitamin $\mathrm{C}$ sebagai pembanding dapat dilihat pada Tbel 4 .

Tabel 4. Data Hasil Uji Antioksidan Vitamin C (Pembanding)

\begin{tabular}{|c|c|c|c|}
\hline $\begin{array}{c}\text { Konsentrasi } \\
\text { (ppm) }\end{array}$ & $\begin{array}{c}\% \\
\text { Inhibisi }\end{array}$ & $\begin{array}{c}\text { Absorbansi Rata-rata } \\
(\mathbf{p p m})\end{array}$ & $\begin{array}{l}\mathrm{IC}_{50} \\
(\mathrm{ppm})\end{array}$ \\
\hline 0 & 0 & 0,203 & \multirow{6}{*}{0,93} \\
\hline 2 & 56,16 & 0,089 & \\
\hline 3 & 63,05 & 0,075 & \\
\hline 4 & 69,46 & 0,062 & \\
\hline 5 & 73,89 & 0,053 & \\
\hline 6 & 81,28 & 0,038 & \\
\hline
\end{tabular}

Selanjutnya, kurva regresi linear Vitamin C dapat dilihat pada Gambar 3.

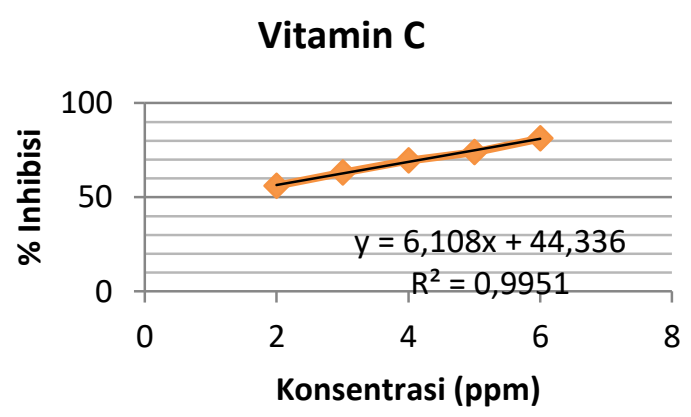

Gambar 3. Kurva Regresi Linear Vitamin C (Pembanding) 


\section{KESIMPULAN}

Kandungan senyawa metabolit sekunder pada buah senggani (Melastoma malabathricum L.) dan buah bit (Beta vulgaris L.) adalah alkaloid, flavonoid, dan tanim. Buah senggani dan buah bit memiliki aktivitas antioksidan yang tergolong dalam kategori sangat kuat, yaitu dengan nilai $\mathrm{IC}_{50}$ sebesar 4,63 ppm dan 7,77 ppm.

\section{DAFTAR PUSTAKA}

Afnidar. (2014). Fitokimia dan Uji Aktivitas Antibakteri Ekstrak Kalus Tumbuhan Sernai (Wedelia blifora L.) DC). JIESBIO, 3(4), 9-16.

Hanani, E. (2005). Identifikasi Senyawa Antioksidan dalam Spons Callyspongia sp, dari Kepulauan Seribu. Departemen Farmasi FMIPAUI Depok.

Handayani, V., Ahmad, A. R., \& Sudir, M. (2014). Uji Aktivitas Antioksidan Ekstrak Metanol Bunga dan Daun Patikala (Etlingera elatior (Jack) R.M.Sm) Menggunakan Metode DPPH. Pharm Sci Res, 1(2), 86-93.

Hasby., Nurhafidhah., \& Akbar, S. A. (2019). The UV-Vis Study on Anthocianin Pigments Activities Extracted from Gayo Arabika Coffee Husks. Elkawnie, 5(2), 147-156.

Hasby., Nurhafidhah., Pamungkas, G., \& Akbar, S. A. (2020). Dye-Sensitized Solar Cells Properties from Natural Dye as Light-Reaping Materials Extracted from Gayo Arabika Coffee Husks. Rasayan J. Chem, 13(1), 3843.
Ivasinova, E., Tokar, M., Mocko, K., Bojnanska, T., Marecek, J., \& Mendelova, A. (2013). Antioxidant activity of selected plant products. Journal of Microbiology, Biotecnology and Food Science, 2(1), 1692-1703.

Mardawati, E. (2008). Kajian Aktivitas Ekstrak Kulit Manggis (Garcinia mangostana. L.) dalam Rangka Pemanfaatan Limbah Kulit Manggis di Kecamatan Puspahiang Kecamatan Tasikmalaya. Bandung: Universitas Padjajaran.

Mustapa, K., Rizky, A., \& Jura, M.R. (2017). Pengaruh Ekstrak Tanaman Putri Malu (Mimosa pudica Linn) terhadap Penurunan Kadar Glukosa Darah pada Mencit (Mus musculus). Jurnal Akademika Kimia, 6(1), 7-14.

Rahmayani, U., Pringgenies, D., \& Djunaedi, A. (2013). Uji aktivitas antioksidan ekstrak kasar keong bakau (Telescopium telescopium) dengan pelarut yang berbeda terhadap metode DPPH (Diphenyl picril hidrazil). Journal of Marine Research, 2(4), 36-45.

Santoso, U. (2016). Antioksidan pangan. Yogyakarta: Gadjah Mada University Press. 